JURNAL ILMU POLITIK, Volume 9 Nomor 1, April 2018

\title{
MARKETING POLITIK DPP PARTAI GERINDRA PADA PEMILU LEGISLATIF 2014
}

\author{
Fahmi Nurdiansyah, Praktisi Hukum \\ Email: fahmi.nurdiansyah09@gmail.com
}

\begin{abstract}
The purpose of this research is to know the implementation in the political marketing of Gerindra Party and some factors encouraging the party to gain a wide range of constituent voters in the legislative elections 2014. The aforementioned evidence reveals that Gerindra Party approached middle class down society and youth, on determining intended voters and this party also focusing on small society (farmer, fisherman, labour, teacher and small trader). In terms of positioning, Gerindra Party put themselves in outside of the government and acknowledge them as the party for small society. In Indonesian political constellation, it can be seen that political party has a high correlation with the power of public figure to increase popularity and electability. Gerindra Party is still introduced Prabowo Subianto as a public figure who can be used to gain a number of voters for the party.
\end{abstract}

Key words: Political Marketing, Gerindra Party, Legislative Elections

\section{PENDAHULUAN}

Marketing politik merupakan konsep yang baru berkembang pada tahun 1980-an, ketika televisi memegang peran penting dalam menyampaikan pesan-pesan komersil kepada pasar. Implementasi konsep marketing politik oleh Bill Clinton dalam persaingan menjadi Presiden Amerika dapat dianggap sebagai tonggak penting sejarah marketing politik (Nursal, 2004: 8). Penerapan marketing politik memberi kontribusi dan warna signifikan dalam hingar-bingar persaingan politik di sejumlah negara maju.

Wring (1996) menunjukkan bahwa aktifitas marketing politik telah lama dilakukan oleh partai-partai politik di Inggris. Dinyatakan bahwa semasa periode Pemilu di Inggris 1929, Partai Konservatif menjadi partai pertama yang menggunakan agen biro iklan (Holford-Bottomley Advertising Service) dalam membantu mendesain dan mendistribusikan poster dan pamflet (Firmanzah, 2007, hlm. 160). Partai Buruh juga memulai penggunaan marketing dalam dunia politik ketika diresmikannya departemen publikasi di tahun 1917, dibantu oleh agen publikasi Egerton Wake yang kemudian berperan aktif dalam kampanye Partai Buruh.

Di Indonesia, khususnya setelah reformasi konsep marketing politik mulai populer dan diterapkan dalam menghadapi Pemilu. Persaingan Parpol yang jumlahnya banyak memaksa setiap elite politik untuk senantiasa membuat kreasi unik dan menarik demi memikat perhatian publik. Salah satu proses kampanye yang penting dilakukan ketika jumlah partai sangat banyak adalah membangun diferensiasi antara satu dengan yang lainnya. Menurut Heywood (2014, hlm. 289) Parpol memiliki peran fundamental bagi jalannya politik modern sehingga peran dan pengaruh mereka seringkali ada begitu saja dengan sendirinya. Sebagai "mesin politik" yang diorganisasikan untuk memenangkan Pemilu dan meraih kekuasaan pemerintahan, partai-partai mulai eksis baru pada awal abad ke-19.

Salah satu ciri utama dari demokrasi adalah suatu konsepsi modern yang menempatkan penyelenggaraan Pemilihan Umum (Pemilu) yang bebas dan berkala sebagai kriteria utama 
bagi sebuah sistem politik agar dapat dikatakan sebagai sistem demokrasi (Schumpeter, 2013: 412). Pemilu merupakan suatu cerminan dari sistem demokrasi, dengan diselenggarakannya Pemilu dianggap dapat menyuarakan suara rakyat yang sesungguhnya.

Pemilu yang terbuka, bebas, dan adil adalah esensi demokrasi, suatu sine qua non yang tidak dapat dielakkan. Melalui Pemilu yang adil, jujur, dan berkala, di dalam sistem itu para calon secara bebas bersaing untuk memeroleh suara dan hampir semua penduduk dewasa berhak memberikan suara. Dengan demikian menurut definisi ini, demokrasi mengandung dua dimensi - kontes dan partisipasi (Huntington, 1995, hlm. 9).

Pasca bergulirnya reformasi peta politik di Indonesia mengalami perubahan yang ditandai dengan munculnya partai-partai baru. Hal ini terlihat pada Pemilu 1999 yaitu Pemilu pertama pada masa reformasi yang diikuti oleh 48 Parpol dan perolehan suara dimenangkan oleh PDIP sebesar 33,74 persen. Pelaksanaan Pemilu 2004 merupakan sejarah penting dalam politik Indonesia karena memungkinkan rakyat memilih wakil mereka untuk menjabat di DPR, DPD, dan DPRD. Pemilu calon anggota DPR, DPD, dan DPRD tahun 2004, yang selanjutnya disebut Pemilu Legislatif diikuti oleh 24 Parpol peserta yang dimenangkan oleh Partai Golkar dengan perolehan suara sebesar 21,58 persen diikuti PDIP pada posisi kedua sebesar 18,53 persen dan diikuti Partai Kebangkitan Bangsa (PKB) dengan perolehan suara 10,57 persen. Partai Demokrat yang notabene partai baru dan dibentuk pada masa reformasi ini sudah menempati posisi 5 (lima) besar dan mencalonkan Susilo Bambang Yudhoyono (SBY) sebagai calon presiden.

Pada Pemilu Legislatif 2009 jumlah peserta Pemilu meningkat dibandingkan sebelumnya. Pemilu ini diikuti oleh 44 Parpol yaitu 38 partai nasional dan 6 partai lokal Aceh. Pemilu Legislatif 2009 ini dimenangkan oleh Partai Demokrat yang ditopang oleh sosok SBY sebagai dewan pembina partai dan juga sebagai presiden RI periode 2004-2009 dengan meraih 20,85 persen suara. Lahirnya Parpol baru pada awal-awal reformasi dan setelah Pemilu tahun 2004 meningkatkan persaingan dalam Pemilu. Dengan sosok sentral seperti Prabowo Subianto yang diusung Partai Gerindra dan juga Wiranto yang diusung Partai Hanura sekaligus ketua umum partai, membuat publik mudah untuk mengenal partai-partai baru ini. Dalam perolehan suara Pemilu Legislatif 2009 masing-masing menempati peringkat ke-8 dan peringkat ke-9.

Pelaksanaan Pemilu 2014 merupakan pemilihan wakil-wakil rakyat secara langsung yang ketiga kalinya di Indonesia. Peserta Pemilu Legislatif 2014 diikuti oleh 12 Parpol. Partai Demokrasi Indonesia Perjuangan (PDIP) tampil sebagai pemenang dengan memeroleh jumlah suara 18,95 persen, posisi kedua ditempati oleh Partai Golkar dengan jumlah suara 14,75 persen, dan Partai Gerindra menempati posisi ketiga dengan jumlah suara 11,81 persen.

Suatu kasus menarik adalah Partai Gerindra. Pada saat partai-partai lain mengalami penurunan suara, Partai Gerindra mengalami kenaikan suara yang sangat signifikan dari 4,46 persen menjadi 11,81 persen. Padahal Partai Gerindra merupakan Parpol yang bisa terbilang baru dalam politik Indonesia. Partai Gerindra pertama kali mengikuti Pemilu tahun 2009. Sebagai partai baru, Partai Gerindra berhasil menempati peringkat ke-8 dalam Pemilu Legislatif 2009 dan masuk dalam posisi 3 besar partai yang mendapatkan suara terbanyak dalam Pemilu Legislatif 2014.

Dari keempat Pemilu pascareformasi dapat dilihat bahwa Pemilu akan senantiasa diikuti banyak Parpol. Dalam kondisi seperti ini, para pemilih tak akan mampu mengingat begitu banyak nama partai dan program-program utama serta nama-nama para kandidat yang ditawarkan suatu partai. Dengan demikian, mayoritas partai-partai yang ikut Pemilu akan sulit dikenal pemilih, apalagi membedakannya dengan partai lain. Cukup beralasan untuk mengatakan bahwa partai-partai tidak gampang mencapai target sasaran dengan cara-cara 


\section{POLITIKA}

JURNAL ILMU POLITIK, Volume 9 Nomor 1, April 2018

kampanye dan kegiatan kehumasan konvensional. Tantangan besar khususnya akan dihadapi partai-partai baru. Tanpa langkah terobosan, partai-partai baru akan sulit untuk meraih suara, bahkan hanya sekadar untuk dikenal baik oleh pemilih. Langkah-langkah terobosan itu hanya bisa dilakukan dengan strategi yang jitu, termasuk menerapkan pemasaran politik (Nursal, 2004, hlm. 10).

Berdirinya partai-partai baru tersebut dapat dikatakan sebagai salah satu indikator bahwa Indonesia semakin demokratis. Hal itu memberikan dampak positif bagi perkembangan politik di Indonesia. Semakin banyak Parpol memberikan peluang lebih besar kepada masyarakat dalam menyalurkan aspirasi politiknya. Rakyat memiliki alternatif pilihan yang lebih beragam kepada partai yang dianggap dapat mewakili suaranya. Kondisi demikian sulit diperoleh saat Pemilu di masa Orde Baru. Reformasi politik yang terjadi juga berdampak pada berubahnya struktur pasar Parpol di Indonesia (Alie, 2013, hlm. 9).

Dalam UU No. 8 Tahun 2012 tentang Pemilihan Umum Anggota DPR, DPD, DPRD, kampanye Pemilu diartikan sebagai kegiatan peserta Pemilu untuk menyakinkan pemilih dengan menawarkan visi, misi, dan program peserta. Dalam kampanye Pemilu anggota DPR, DPD, dan DPRD ini bertujuan untuk menyakinkan para pemilih dalam memeroleh dukungan sebesar-besarnya dan semaksimal mungkin, dengan menawarkan visi, misi, dan program masing-masing calon anggota DPR, DPD, dan DPRD.

Melihat fakta empiris Partai Gerindra yang berhasil menempati posisi 3 besar dalam Pemilu Legislatif 2014 dan meningkatnya perolehan suara Partai Gerindra yang signifikan adalah fenomena yang menarik untuk dikaji. Berdasarkan uraian di atas, penelitian ini bertujuan untuk mengetahui dan menganalisis strategi marketing politik yang dilakukan oleh Partai Gerindra dalam Pemilu Legislatif 2014 dan untuk mengetahui dan menganalisis faktor-faktor yang mendorong Partai Gerindra meraih suara konstituen dalam Pemilu Legislatif 2014.

\section{KAJIAN TEORITIK}

Menurut Johnson (2008, hlm. 67) marketing politik didefinisikan sebagai "proses kandidat dalam menyampaikan ide-ide yang diarahkan kepada pemilih dalam rangka untuk memenuhi kebutuhan dan dengan demikian mendapatkan dukungan mereka untuk kandidat dan ide-ide yang bersangkutan" (political marketing was defined as "the process by the which political candidates and ideas are directed at the voters in order to satisfy needs and thus gain their support for the candidate and ideas in question").

Partai dapat memanfaatkan berbagai alat pemasaran termasuk profil pemilih, segmentasi, targeting dan e-marketing untuk menginformasikan komunikasi mereka. Mereka juga dapat menanggapi keterangan pasar dalam cara mereka merancang produk politik yang mereka tawarkan, menjadi berorientasi pasar daripada orientasi penjualan (parties can utilize a range of marketing tools including voter profiling, segmentation, micro-targeting and e-marketing to inform their communication. They can also respond to market intelligence in the way they design the political product they offer, becoming market-oriented rather than primarily sales-oriented) (Less-Marshment, 2009, hlm. 1).

Metode marketing canvassing juga bisa dimanfaatkan Parpol atau kandidat dalam menjual produk politik. Canvassing akan membantu Parpol mengiklankan produk politik. Dengan melakukan kontak yang baik, menawarkan produk yang baik, canvassing bisa dijadikan alat pemasaran yang dibutuhkan. Keberhasilan canvassing tergantung pada Parpol atau kandidat itu sendiri. Jika Parpol berhasil, maka Parpol layak untuk mendapatkan suara pemilih dalam persaingan politik (Levinson, 1984, hlm. 64).

Konsep marketing dalam dunia politik disebut sebagai marketing politik. Menurut Firmanzah (2007, hlm. 21) marketing politik merupakan metode dan konsep aplikasi 
marketing dalam konteks politik. Tentunya terdapat perbedaan antara situasi dunia politik dengan dunia komersial yang perlu disesuaikan dalam pemasaran politik. Pemasaran politik menjadi suatu kajian tersendiri dalam dunia politik.

Kotler dan Levy (1969) dalam Firmanzah (2007) beragumen bahwa penggunaan konsep marketing tidak terbatas hanya pada institusi bisnis saja. Kenyataan ini telah menarik perhatian, banyak pihak yang menerapkan ilmu marketing di luar konteks organisasi bisnis. Ilmu marketing tidak hanya terbatas pada cara menjual produk tetapi lebih dari itu, seharusnya dipahami juga sebagai cara organisasi dalam memuaskan konsumen.

Marketing politik dipahami sebagai penyebaran gagasan-gagasan politik dengan menerapkan prinsip-prinsip pemasaran komersial. Hal itu menunjukkan kecenderungan antara dunia politik dan dunia bisnis. Dunia politik dan dunia bisnis, memang semakin dekat, terutama karena banyak aktor politik yang berasal dari dunia bisnis. Kemampuan dan pengalaman para pebisnis melakukan lobi, negoisasi dan pemasaran, dengan mudah diterapkan atau diaplikasikan dalam komunikasi politik (Arifin, 2011, hlm. 145).

Hal inilah yang menyebabkan pendekatan marketing politik menjadi faktor penting dalam memenangkan Pemilu, baik itu Pemilu Legislatif maupun Pemilu Presiden. Dengan demikian, untuk memenagkan persaingan politik dalam arena Pemilu, maka pemasaran politik menyediakan berbagai senjata yang diperlukan. Strategi pemasaran politik ini meliputi segmentasi, targeting, dan positioning.

Dengan membuat segmentasi, dapat merangkul seluruh segmen dengam program pencitraan yang dimiliki. Efektivitas pencitraan harus dijalankan dengan menentukan target audience yang akan menjadi sasaran program (Wasesa, 2011, hlm. 200). Setiap partai dan kandidat memiliki citra sendiri di lingkungan di mana ia bergerak. Citra tersebut merupakan gambaran yang ada dalam bayangan masyarakat atau pemilih tentang partai atau kandidat, pada periode tertentu. Terkadang gambaran ini kosong, sehingga masyarakat atau pemilih belum mengenal partai atau kandidat. Melalui target image ini kita merencanakan strategi, membangun citra yang baik dan positif. Dengan tema yang lebih baik, solusi yang lebih, penawaran figur yang lebih baik dan kompetensi yang lebih baik pula (Schroder, 2010, hlm. 269).

Nimmo (2005, hlm. 193) mengungkapkan rencana kampanye mencakup empat segi maksud ide yang melandasinya. Pertama, ada formasi awal dari organisasi kampanye, terdiri atas politisi, jurukampanye profesional, dan sukarelawan dari kalangan masyarakat. Selain mendirikan organisasi kampanye, rencana kampanye merinci bagaimana dana harus dikumpulkan dan dipergunakan, bagaimana melakukan riset untuk mendapatkan informasi yang diperlukan mengenai masalah yang dikemukakan, dan bagaimana menyampaikan pesan kandidat.

Di banyak negara yang sudah stabil melakukan Pemilu secara reguler seperti di Amerika Serikat dan Eropa, teori tentang voting behavior sudah demikian berkembang. Hal ini disebabkan banyak studi perilaku memilih di negara-negara tersebut terutama di Amerika Serikat, Kanada, Inggris, Jerman, Belanda, Perancis, dan sebagainya. Dengan adanya sejumlah studi perilaku memilih, maka tersedia data yang memadai untuk melakukan inferensi-inferensi teoritis (Asfar, 2006, hlm. 137).

Dalam studi perilaku memilih, secara garis besar ada tiga model untuk menjawab pertanyaan-pertanyaan tersebut. Model sosiologis, model psikologis, dan model pilihan rasional atau ekonomi politik. Ketiga model ini bersaing untuk memberikan jawaban yang lebih menyakinkan bagi pertanyaan-pertanyaan di atas (Mujani dan Liddle, 2011, hlm. 4). 


\section{POLITIKA}

JURNAL ILMU POLITIK, Volume 9 Nomor 1, April 2018

Parpol merupakan keharusan dalam kehidupan politik modern yang demokratis. Sebagai suatu organisasi, Parpol secara ideal dimaksudkan untuk mengaktifkan dan memobilisasi rakyat, mewakili kepentingan tertentu, memberi jalan kompromi bagi pendapat-pendapat yang saling bersaing, serta menyediakan sarana suksesi kepemimpinan politik secara sah (legitimate) dan damai (Amal, 2012). Parpol memainkan peran yang menentukan dalam sebuah sistem demokrasi modern dan merupakan pilar utama dalam pranata sistem politik. Parpol menerjemahkan nilai dan kepentingan suatu masyarakat dalam proses dari bawah ke atas sehingga nilai dan kepentingan dari masyarakat itu sendiri menjadi rancangan undang-undang negara, peraturan-peraturan yang mengikat, dan program bagi rakyat (Meyer, 2012, hlm. 30).

Menurut Sartori Parpol adalah suatu kelompok politik yang mengikuti Pemilu dan melalui Pemilu itu, mampu menempatkan calon-calonnya untuk menduduki jabatan-jabatan publik (A party is any political group that present at elections, and is capabie of placing through elections candidates for public office) (Budiarjo, 2008, hlm. 405).

Parpol sebagai bagian penting masyarakat politik menjadi penyeimbang kekuasaan eksekutif ketika wakil-wakilnya di parlemen menyelenggarakan kontrol efektif terhadap jalannya kekuasaan. Dalam pandangan Dahl tersebut Parpol menjadi salah satu lembaga perwakilan dan lembaga pengontrol maupun penyeimbang. Artinya, dengan lahirnya Parpol, maka akan menjalankan sistem demokrasi kepartaian dan saling memberikan masukan demi berjalannya pemerintahan yang baik, serta bentuk aspirasi dan mengambil keputusan sesuai dengan harapan masyarakat (Dahl 1972, dalam A. Ways, 2015, hlm. 126).

\section{METODE PENELITIAN}

Pendekatan yang digunakan pada penelitian ini adalah pendekatan kualitatif dengan metode studi kasus. Pendekatan ini digunakan oleh peneliti karena dengan metode ini permasalahan dapat digambarkan dengan jelas dan terperinci mengenai strategi pemasaran politik Partai Gerindra. Pendekatan dalam penelitian ini merujuk pada tujuan penelitian yaitu memberikan gambaran yang komprehensif tentang strategi pemasaran politik yang digunakan oleh Partai Gerindra pada Pemilu Legislatif 2014.

Menurut Creswell (2014, hlm. 135) penelitian studi kasus adalah pendekatan kualitatif yang penelitiannya mengeksplorasi kehidupan nyata, sistem terbatas kontemporer (kasus) atau beragam sistem terbatas (berbagai kasus), melalui pengumpulan data yang detail dan mendalam yang melibatkan beragam sumber informasi atau sumber informasi majemuk (misalnya, pengamatan, wawancara, bahan audiovisual, dan dokumen serta berbagai laporan), dan melaporkan deskripsi kasus dan tema kasus.

Penentuan informan dalam penelitian ini dilakukan dengan cara purposive sampling. Pengambilan subjek penelitian atau informan dengan menggunakan purposive sampling dinyatakan cocok dengan masalah penelitian yang dibahas. Penentuan informan didasarkan atas tujuan peneliti dalam mengungkapkan masalah yang diangkat dalam penelitian. Subjek penelitian ditentukan berdasarkan orang yang dianggap paling tahu tentang informasi yang dibutuhkan dalam penelitian, sehingga akan memudahkan peneliti dalam menelusuri situasi yang diteliti.

Penelitian ini menggunakan data primer yang diperoleh melalui wawancara mendalam terhadap sejumlah informan. Menurut Stedward (1997) secara khusus, wawancara adalah alat yang baik untuk menghidupkan topik riset. Wawancara juga merupakan metode bagus untuk pengumpulan data tentang subjek kontemporer yang belum dikaji secara ekstensif dan tidak banyak literatur yang membahasnya (Harrison, 2009, hlm. 104). Data ini merupakan data utama yang kemudian dianalisis. Sementara data sekunder adalah data berupa buku-buku, 
majalah, tabloid, koran, dokumen, catatan, serta perangkat perundang-undangan atau peraturan yang terkait dengan topik penelitian.

Teknik analisis data dalam penelitian ini menggunakan metode analisis data kualitatif, yakni data yang tersedia diambil simpulannya, kemudian diuraikan dalam bentuk naratif. Pertama, reduksi data. Reduksi data dimaknai sebagai proses seleksi, titik fokus pada penyederhanaan, abstraktisasi transformasi data kasar dari catatan penelitian. Kedua, display data. Dalam penelitian ini, penyajian data merupakan segudang informasi yang tersusun dan membuka peluang dilakukannya penarikan simpulan dan penetapan keputusan mengenai temuan-temuan awal di lapangan, untuk disajikan dalam bentuk matriks. Ketiga, verifikasi. Teknik paling akhir dari penelitian ini adalah menarik simpulan-simpulan matang dari hasil yang dilakukan di tahap pertama dan tahap kedua. Dari hasil simpulan tersebut ditampilkan hasil-hasil penelitian.

\section{HASIL PENELITIAN}

Hasil penelitian menunjukkan bahwa dalam Pemilu Legislatif 2014, Partai Gerindra melakukan berbagai upaya dan strategi untuk memenangkan suara konstituen. Strategi yang dijalankan adalah menjaring dukungan sebesar-besarnya dari masyarakat melalui turun langsung ke masyarakat, kemudian melalui media massa yang diselenggarakan oleh badan komunikasi Partai Gerindra.Partai Gerindra membidik segmen masyarakat kelas bawah dan segmen pemuda, dalam menentukan target sasaran Partai Gerindra memfokuskan pada kelompok masyarakat kecil (petani, nelayan, buruh, guru, dan pedagang kecil). Dalam hal positioning, Partai Gerindra memposisikan diri berada di luar pemerintahan dan memposisikan diri sebagai partai rakyat kecil. Peningkatan perolehan suara Partai Gerindra dalam Pemilu Legislatif 2014 dilandasi beberapa faktor diantaranya, figur Prabowo, iklan politik, dan platform Partai Gerindra.

\section{PEMBAHASAN}

\section{Analisis Penerapan Marketing Politik Partai Gerindra dalam Pemilu 2014}

Secara umum dapat dikatakan bahwa strategi pemasaran politik yang dilakukan Partai Gerindra menjadikan figur Prabowo Subianto sebagai brand atau produk politik sebagai produk utama. Mengingat konstelasi politik Indonesia masih didominasi oleh kekuatan seorang figur. Dalam tahap segmentasi, targeting, hingga positioning dapat diperhatikan bahwa figur Prabowo Subianto selalu muncul dan menjadi ujung tombak dari strategi pemasaran yang dilakukan Partai Gerindra.

Peneliti Lembaga Ilmu Pengetahuan Indonesia (LIPI) Prof. Ikrar Nusa Bhakti, menuturkan bahwa faktor Prabowo Subianto tidak bisa dilepaskan dari kesuksesan Partai Gerindra masuk posisi tiga besar peraih suara terbanyak. Menurutnya, Partai Gerindra merupakan partai yang cukup siap dalam menghadapi pertarungan Pemilu. Prabowo Subianto yang kerap muncul di televisi menjadi satu dari beberapa faktor pemicu partai ini meraih suara di atas 10 persen. Misalnya, saat Prabowo Subianto kerap memberikan ucapan selamat hari besar kepada umat beragama di Indonesia (sebagaimana diberitakan oleh tribunnews.com, 10 April 2014).

Strategi marketing politik yang dilakukan Partai Gerindra berhasil membangun citra Prabowo Subianto sebagai sosok yang ideal. Seperti yang diungkapkan oleh Nimmo (2010, hlm. 6) terkait citra personal dalam politik memiliki tiga manfaat diantaranya, Pertama, betapa pun benar atau kelirunya, lengkap atau tidak lengkapnya pengetahuan orang tentang politik, hal itu memberikan jalan kepadanya untuk memahami peristiwa politik tertentu. Kedua, kesukaan atau ketidaksukaan umum pada citra seseorang tentang politik menyajikan dasar untuk menilai objek politik. Ketiga, citra diri seseorang memberikan cara menghubungkan 


\section{POLITIKA}

JURNAL ILMU POLITIK, Volume 9 Nomor 1, April 2018

dirinya dengan orang lain. Pencitraan yang dilakukan Partai Gerindra tidak serta merta instan, tetapi secara maraton sejak tahun 2009 hingga menjelang Pemilu tahun 2014.

Citra Parpol tidak dapat dibangun dalam waktu singkat, namun membutuhkan proses yang panjang. Citra hanya dapat dibangun melalui aktivitas tokoh dan Parpol di masyarakat. Ketika tokoh Parpol duduk dalam pemerintahan dapat menunjukkan prestasi, maka akan mendapat penilaian yang positif dari masyarakat. Sebaliknya, ketika ada tokoh Parpol yang melakukan kesalahan, seperti terlibat kasus korupsi, maka akan menjatuhkan reputasi Parpol. Fenomena ini terjadi pada Partai Demokrat saat Pemilu 2014, perolehan suara Partai Demokrat menurun jika dibandingkan pada Pemilu sebelumnya, dikarenakan beberapa elite partai yang terjerat kasus korupsi.

Hal ini berbanding terbalik dengan apa yang diperoleh Partai Gerindra pada Pemilu 2014. Citra positif yang dibangun Partai Gerindra juga didukung figur Prabowo Subianto, dengan gencarnya iklan baik di mediacetak maupun elektronik dengan mengkritisi kebijakan-kebijakan pemerintah. Program-program kesejahteraan, kesehatan, pendidikan, dan pemberantasan korupsi yang digagas Partai Gerindra dapat membangun citra positif di masyarakat. Oleh karena itu, citra Parpol merupakan salah satu pilar partai yang perlu dibangun dengan kuat agar dipilih oleh masyarakat. Kegagalan partai dalam membangun citra positif akan berdampak terhadap kemerosotan dukungan konstituen, yang akhirnya juga gagal dalam memenangkan Pemilu.

Berdasarkan analisis peneliti, Partai Gerindra memiliki ketergantungan akut terhadap figur Prabowo Subianto dalam artian proses pembangunan partai sepertinya lebih difokuskan sebagai sebuah upaya untuk menyokong seorang Prabowo Subianto duduk di kursi R1-1. Partai Gerindra bukan dibentuk melalui platform yang dibangun lewat gerakan sebuah partai. Hal ini terlihat dalam sejarah pembentukan Partai Gerindra sendiri yang memerlihatkan hasrat seorang Prabowo Subianto yang terkesan elitis.

Kebesaran Partai Gerindra dalam Pemilu 2014 masih bisa dikatakan gelembung udara karena fenomena partai ini muncul disebabkan iklan politik yang besar dan frekuensi yang tinggi. Hal ini belum diimbangi dengan kuatnya infrastruktur dan image yang sesuai dengan iklannya, terutama di tingkat bawah. Begitu pula dengan mesin politik, partai ini hanya bergerak pada satu figur dan bekerjanya iklan-iklan dalam hal ini pendekatan above the line dalam pengertian marketing politik, mesin politik Partai Gerindra yang belum teruji. Sebagian caleg partai ini pun terlihat kurang populis di mata masyarakat.

\section{Analisis Faktor-Faktor Meningkatnya Suara Partai Gerindra dalam Pemilu 2014}

Dalam konstelasi politik Indonesia ketokohan seorang figur dalam memimpin partai masih menjadi kunci keberhasilan sebuah Parpol. Tanpa keberadaan tokoh sentral, Parpol akan sulit bertahan. Peningkatan perolehan suara Partai Gerindra pada Pemilu Legislatif 2014 tidak terlepas dari figur Prabowo Subianto. Menokohkan tokoh-tokoh tertentu, bukan hanya figur tetapi untuk menggerakkan partai. Dengan adanya tokoh dalam Parpol, maka "mesin politik" akan berjalan, sebab pengaruh tokoh tidak hanya berada di tingkat nasional, melainkan juga di daerah.

Pengamat politik Yunarto Wijaya, mengatakan gejala ketergantungan partai terhadap figur penarik suara semakin kuat. Gejala itu merata di hampir semua partai besar, seperti Partai Demokrasi Indonesia Perjuangan, Partai Gerindra, dan Partai Demokrat. Begitu juga dengan pemilih Partai Gerindra. Menurutnya, pemilih partai itu tertarik kepada Ketua Umum Prabowo Subianto. Sebanyak 47,9 persen responden tertarik dengan figur bekas Komandan Jenderal Komando Pasukan Khusus itu, sedangkan responden yang tertarik dengan program Partai Gerindra hanya 5,7 persen (rumahpemilu.org, 27 Maret 2014). 
Semakin kuatnya citra Prabowo Subianto menjadi kunci penting dalam mendongkrak popularitas dan elektabilitasnya, serta sebagai faktor utama dalam meningkatnya perolehan suara Partai Gerindra dalam Pemilu 2014. Keberhasilan Partai Gerindra ini juga mengantarkan Prabowo Subianto sebagai calon presiden pada Pilpres 2014 berdampingan dengan Hatta Rajasa sebagai calon wakil presiden. Jargon “Gerindra Menang, Prabowo Presiden” yang digaungkan sebagai bentuk motivasi positif kepada seluruh kader dan simpatisan Partai Gerindra agar berjuang untuk memenangkan Partai Gerindra pada Pemilu 2014. Jargon ini tidak hanya melekat bagi para kader dan simpatisan melainkan bagi masyarakat luas. Jargon ini dapat dikatakan sebagai jargon utama Partai Gerindra pada Pemilu 2014.

Selain mengandalkan figur Prabowo Subianto, Partai Gerindra juga melakukan kampanye masif yang dilakukan di media cetak, elektronik, dan media sosial. Partai Gerindra memanfaatkan media-media tersebut dengan cukup baik untuk mensosialisasikan program-program kerakyatan yang diusungnya. Pada Pemilu 2014 Partai Gerindra menghabiskan sekitar Rp. 434 miliar untuk kampanye dan merupakan dana kampanye terbesar dibandingkan dengan partai-partai lainnya (metrotvnews.com, 23 April 2014). Sebagian besar biaya itu dihabiskan untuk iklan-iklan di media elektronik dan cetak.

Dalam hal ini media televisi memiliki peran besar dalam menciptakan realitas politik. Tidak mengherankan jika selanjutnya para aktor iklan politik tersebut meraih peningkatan popularitas dalam waktu yang singkat, selain popularitas menanjak, elektabilitas pun turut bergerak naik. Melalui figur Prabowo Subianto sukses membawa Partai Gerindra masuk dalam tiga besar pemenang Pemilu 2014. Kesuksesan tersebut merupakan hasil konstruksi media terhadap sosok Prabowo Subianto melalui iklan politiknya.

Figur Prabowo Subianto yang dikenal tegas, yang merupakan antitesis incumbent yang dikenal lamban dan kurang tegas dalam mengambil keputusan secara cepat bisa memeroleh dukungan yang luas. Apalagi peran media massa dengan iklan Partai Gerindra yang efektif, fokus, dan efesien cepat memberikan nilai tambah dan citra positif Prabowo Subianto. Partai Gerindra dan Prabowo Subianto menjadi ikon baru terutama di kalangan masyarakat bawah dan pemuda. Program penggalangan massa yang cenderung agresif dan komunikasi politik yang efektif dan konsisten membuat citra politik Partai Gerindra terangkat.

Strategi marketing politik yang diterapkan oleh Partai Gerindra berhasil meningkatkan perolehan suara dibanding Pemilu sebelumnya. Figur Prabowo Subianto, iklan politik dan platform partai merupakan faktor yang memengaruhi kenaikan suara Partai Gerindra dalam Pemilu 2014. Dengan medium iklan politik yang terfokus, simpel, dan menarik, dengan figur Prabowo Subianto popularitas Partai Gerindra meningkat tajam.

Di sisi lain Partai Gerindra masih menganut sistem patronase. Sistem tersebut adalah fenomena yang biasa terjadi dalam tubuh partai karena konsekuensi dari sistem multipartai. Berbeda dengan partai lain Partai Gerindra sengaja didirikan untuk mengusung Prabowo Subianto sebagai calon presiden. Prabowo Subianto menjadi center atau patron dari partai ini termasuk di bidang pendanaannya. Besarnya dukungan finansial Prabowo Subianto menjadi kelemahan Partai Gerindra, jika tidak diimbangi dengan jaringan kader yang militan di tingkat bawah.

\section{PENUTUP}

\section{Simpulan}

Setelah menganalisis dan membahas data yang diperoleh dari hasil wawancara semua informan dan didukung oleh sumber data lain, maka dapat ditarik beberapa kesimpulan sebagai berikut. Pertama, Partai Gerindra membidik segmen masyarakat kelas bawah dan segmen pemuda, dalam menentukan target sasaran Partai Gerindra memfokuskan pada kelompok 


\section{POLITIKA}

JURNAL ILMU POLITIK, Volume 9 Nomor 1, April 2018

masyarakat kecil (petani, nelayan, buruh, guru, dan pedagang kecil). Dalam hal positioning, Partai Gerindra memposisikan diri berada di luar pemerintahan dan memposisikan diri sebagai partai rakyat kecil.

Kedua, Partai Gerindra masih mengandalkan sosok Prabowo Subianto sebagai sosok yang menjadi pendongkrak utama perolehan suara partai. Sosok ini menjadi sangat kuat baik di internal partai, maupun di eksternal partai. Partai Gerindra menjadikannya sebagai produk utama yang dijual kepada masyarakat. Figur Prabowo Subianto memiliki peranan penting dalam keberhasilannya membangun popularitas dan elektabilitas partai.

Ketiga, selain figur, penggunaan iklan politik oleh Partai Gerindra khususnya media televisi memberikan pengaruh terhadap perolehan suara partai. Melalui iklan di sejumlah media massa terutama televisi, Partai Gerindra mencoba menawarkan jalan keluar atas persoalan yang terus dihadapi bangsa, seperti kemiskinan, kekurangan pangan, krisis energi, ketimpangan ekonomi, kesenjangan sosial, dan lain sebagainya. Selain beriklan di media elektronik dan cetak, Partai Gerindra juga menyasar media sosial yang sebenarnya cukup efektif sebagai sarana membangun image partai pada pengguna media sosial.

\section{Saran}

Berdasarkan hasil penelitian dan kesimpulan, adapun beberapa saran yang dapat dikemukakan sebagai berikut. Terlepas dari keberhasilan Partai Gerindra menempati posisi tiga besar pada Pemilu 2014, ada beberapa catatan yang harus diperhatikan. Hal ini merujuk pada strategi marketing Partai Gerindra lebih didominasi oleh marketing dari ketokohan Prabowo Subianto. Upaya pembanguanan image partai yang tergolong sukses ini juga menjadi masalah kedepannya. Partai Gerindra akan krisis tokoh sentral di masa yang akan datang apabila Prabowo Subianto sudah tidak lagi aktif dalam politi Indonesia. Hal ini akan berpengaruh pada perolehan suara Partai Gerindra di masa yang akan datang akibat sudah tidak memiliki figur atau icon partai yang visioner.

Partai Gerindra perlu melakukan proses kaderisasi yang jelas, sebagai partai yang masih relatif baru kaderisasi penting dilakukan. Hal ini bukan hanya akan menciptakan tokoh, namun juga menciptakan sistem yang unggul. Diharapkan Partai Gerindra tidak hanya bergantung pada sosok figur saja. Nantinya jangan sampai orang melihat bahwa Prabowo Subianto adalah Partai Gerindra dan Partai Gerindra adalah Prabowo Subianto. Partai Gerindra harus menjadi partai yang kolektif dengan keunggulan sumber daya kadernya.

Bagi masyarakat pemilih, hendaknya tidak terjebak pada faktor ketokohan dan iklan politik suatu partai tanpa memetimbangkan aspek-aspek lainnya. Masyarakat harus mengevaluasi apakah figur tersebut memiliki kompetensi, kredibilitas, dan kontribusi terhadap bangsa. Masyarakat sebaiknya memilih figur politik yang memang berintegritas tinggi, kredibel, amanah, dan kompeten dalam memimpin negara. Faktor-faktor seperti itu harus dipertimbangkan agar pemimpin yang terpilih benar-benar pemimpin yang dapat membawa kemajuan bangsa dan meningkatkan kesejateraan masyarakat. Selain itu, masyarakat pemilih dalam memilih Parpol bukan sekadar ikut-ikutan atau karena paksaan pihak-pihak tertentu. Pilihan harus dilandasi rasionalitas dan diimbangi dengan hati nurani sehingga akan meningkatkan kualitas Pemilu di Indonesia. 


\section{DAFTAR RUJUKAN}

Alie, Marzuki2013, Pemasaran politik di era multipartai, Expose, Jakarta.

Amal, Ichlasul (Ed.) 2012, Teori-teori mutakhir partai politik, Tiara Wacana, Yogyakarta.

Arifin, Anwar2011, Komunikasi politik, Graha Ilmu, Yogyakarta.

Arifin, Anwar2014, Politik pencitraan, pencitraan politik, Graha Ilmu, Yogyakarta.

Asfar, Muhammad2006,Pemilu dan perilaku memilih 1955-2004, Pustaka Eureka, Surabaya.

Budiarjo, Miriam2007, Dasar-dasar Ilmu Politik, Gramedia Pustaka Utama, Jakarta.

Creswell. John W2014, Penelitian kualitatif dandesain riset memilih diantara lima pendekatan, Pustaka Pelajar, Yogyakarta.

Creswell. John W2016, Research design: Pendekatan metode kualitatif, kuantitatif, dan campuran, Pustaka Pelajar, Yogyakarta.

Firmanzah2007, Marketing politik antara pemahaman dan realitas, Yayasan Obor Indonesia, Jakarta.

Firmanzah2008, Mengelola partai politik: Komunikasi dan positioning ideologi politik di era demokrasi, Yayasan Obor Indonesia, Jakarta.

Firmanzah2010, Persaingan, legitimasi kekuasaan, dan marketing politik, Yayasan Obor Indonesia, Jakarta.

Harisson, Lisa2009, Metodologi penelitian politik, Prenada Media Group, Jakarta.

Heywood, Andrew2014, Politik, Pustaka Pelajar, Yogyakarta.

Huntington, Samuel P1995, Gelombang demokratisasi ketiga, PT Intermasa, Jakarta.

Johnson, Dennis W (Ed.)2008, Routledge handbook of political management, Taylor \& Francis e-Library, UK.

Less-Marshment, Jennifer, Stromback, Jesper dan Rudd, Chris (Eds.)2009, Global political marketing, Taylor \& Francis e-Library, UK.

Levinson, Jay Conrad1984, Guerrilla marketing, Houghton Mifflin Company, Boston.

Meyer, Thomas2012, Peran partai politik dalam sebuah sistem demokrasi: Sembilan tesis, Friedrich Ebert Stiftung (FES), Jakarta.

Mujani, Saiful, Liddle, R. William dan Ambardi, Kuskridho2012, Kuasa rakyat, Mizan Publika, Bandung.

Nimmo, Dan2005, Komunikasi politik: Komunikator, pesan, dan media, PT Remaja Rosdakarya, Bandung.

Nimmo, Dan2010, Komunikasi politik: Khalayak dan efek, PT Remaja Rosdakarya, Bandung.

Nursal, Adman2004, Political marketing: Strategi memenangkan pemilu, sebuah pendekatan baru kampanye pemilihan DPR, DPD, Presiden, Gramedia Pustaka Utama, Jakarta.

Schroder, Peter2010, Strategi politik, Friedrich Ebert Stiftung (FES), Jakarta. 


\section{POLITIKA}

JURNAL ILMU POLITIK, Volume 9 Nomor 1, April 2018

Schumpeter, Joseph A2013, Capitalism, socialism anddemocracy, Pustaka Pelajar, Yogyakarta.

Wasesa, Silih Agung2011, Political branding andpublic relations, Gramedia Pustaka Utama, Jakarta.

Ways, Muliansyah A2015, Political: Ilmu Politik, demokrasi, partai politik \&welfare state, Buku Litera, Yogyakarta. 